\title{
Chemical composition of hydroethanolic extracts from five species of the Passiflora genus
}

\author{
Marna E. Sakalem, " Giuseppina Negri, Ricardo Tabach
}

Department of Psychobiology, Universidade Federal de São Paulo, Brazil.

\begin{abstract}
The diversified genus Passiflora is well distributed all over Brazil, and many species have been long used as medicinal plants, mainly against anxiety disturbances. This effect has been attributed to its rich flavonoid composition. Flavonoids' main class, flavonoid glycosides, has presented central action, particularly as sedativehypnotic, anxiolytic and analgesic. The objective of the present study was to make a phytochemical screening of five little studied Passiflora species, in order to evaluate their phenolic composition. For this aim, HPLC-DAD-ESI-MS/MS was used. After the preparation of the hydroalcoholic extracts, each species was evaluated by direct injection electrospray ionization (ESI) and tandem mass spectrometry. Although belonging to the same genus, the composition of each species presented particularities; this justifies the importance of studies aiming for the phenolic composition of different Passiflora species. Flavones $C$-glycosides were detected in all extracts, and are found as the main constituents in $P$. vitifolia, $P$. coccinea, $P$. bahiensis and $P$. sidifolia. In this last one, flavone-6,8-di- $C$-glycoside, apigenin-6- $C$-rhamnosyl-8- $C$-arabinoside are present in high content. Cyclopassiflosides were found in high content together with cyanogenic glycosides in $P$. quadrangularis, while in $P$. coccinea, besides flavones- $C$ glycosides were also found procyanidins.
\end{abstract}

Received 9 May 2012

Accepted 31 Jul 2012

Available online 18 Sep 2012

Keywords:

Passiflora bahiensis

Passiflora coccinea

Passiflora quadrangularis

Passiflora sidifolia

Passiflora vitifolia

HPLC-DAD-ESI-MS/MS

ISSN 0102-695X http://dx.doi.org/10.1590/S0102$695 \mathrm{X} 2012005000108$

\section{Introduction}

The genus Passiflora L., Passifloraceae, comprises about 520 species of dicotyledonous plants. Their majority occurs in Central and South America, but some are also present in North America, Southeast Asia and Australia (Dhawan et al., 2004). Several of them have a history of use as traditional herbal medicines. Passiflora incarnata L. is an example of an important herbal drug, widely used in contemporary Western phytotherapy, besides being used for a long time as an anxiolytic agent in folk medicine to treat anxiety, and probably the most widely studied so far (Sarris et al., 2012; Singh et al., 2012). The most commercialized species is P. edulis Sims; different populations of this species were distributed mainly according to the fruit color: the population with yellow fruit was named Passiflora edulis fo. Alavicarpa, while the typical form of the species, which has purple fruit, was established as Passiflora edulis fo. edulis (Li et al., 2011). Passiflora was listed as official plant drug in the 1970s and 1990s by the pharmacopoeias of America, Britain, Germany, France, Switzerland, Egypt and India (Lakhan \& Vieira, 2010; Fiebich et al., 2011; Sarris et al., 2012).

Flavonoid glycosides, the main class of flavonoids, are present in high amounts in most of the Passiflora species studied so far, being the main component in several of them (Wohlmuth et al., 2010). Schaftoside, isoschaftoside, isoorientin. orientin, isovitexin and vitexin were chosen as standards for authentication of 115 samples of different species of the genus Passiflora, due to their presence in the genus (Abourashed et al., 2002). Isoorientin is the main flavone found in passion fruit pulp Passiflora edulis fo. flavicarpa O. Deg. (Zeraik \& Yariwake, 2010). Monoterpenoids were isolated from the fruit pulp of Passiflora edulis fo. flavicarpa O. Deg. (Osorio et al., 2000). Lucenin-2, vicenin-2, isoorientin, isovitexin, luteolin-6- $C$-chinovoside and luteolin-6- $C$-fucoside were isolated from the leaves of Passiflora edulis fo. flavicarpa, but not in Passiflora edulis fo. edulis (Li et al., 2011). $\beta$-carboline or indole alkaloids (harmane, harmine, and harmol) were also found at low contents in Passiflora species through thin layer chromatography (Lutomski \& Malek, 1975; Lutomski et al., 1975) and also using a reversed phase High Performance Liquid Chromatography (Rehwald et al., 1995; Grice et al., 2001). Saponins cyclopassiflosides were found in $P$. quadrangularis (Orsini et al., 1986, 1987), P. alata (Reginatto et al., 2001) and P. edulis (Yoshikawa et al., 2000a,b). Cyclopentanoid cyanohydrin glucosides were found in Passiflora mixta (Bylov et al., 2004). Cyanogenic glucosides, such as diastereomers of 
phenylcyano glycosides, were isolated from the methanol extract of dried vines of $P$. quadrangularis (Saeki et al., 2011). Cyanogenic glycosides were also found in Passiflora foetida (Carvalho et al., 2011).

Flavonoid glycosides have been shown to exert Central Nervous System (CNS) mediated activities, particularly as sedative-hypnotics, anxiolytic and analgesics. They represent the most frequently found compounds in $P$. incarnata, such as vitexin, isovitexin, orientin and 2-xylosyl-vitexin (Wohlmuth et al., 2010). The flavonoid chrysin, present in this species, showed CNS depressant activity by agonizing the GABA-benzodiazepine receptor. While that other constituents, such as, amino acids (like GABA) and harmala alkaloids (reversible monoamine oxidase-A inhibitor) also carried out important activities in central nervous system (Barbosa et al., 2008; Aslanargun et al., 2012; Singh et al., 2012). The glycoside myricitrin, present in Avena saliva was effective on the Elevated Plus Maze, a wide used rodent model for anxiety-like behavior, showing a clear anxiolytic effect with no signs of sedation (Fernandez et al., 2009). In addition, a commercial extract of $P$. incarnata with a high content of $C$-glycosyl flavones demonstrated, in vivo, GABAmediated anxiolytic activity (Grundmann et al., 2008). $P$. incarnata mediated many pharmacological effects via modulation of the GABA system, including affinity to GABAA and GABAB receptors, and effects on GABA uptake (Appel et al., 2011).

In the present study, the hydroethanolic extract of five species of this genus were analyzed. $P$. quadrangularis L. is a wild vine, relatively abundant in some regions of the tropical America. The fruit has a slightly acidic pulp with a pleasant and refreshing aroma (Antognoni et al., 2007). In previous studies by other authors, its hydroalcoholic extract exhibited an anxiolytic effect, but not the aqueous extract (de Castro et al., 2007). Passiflora sidifolia is a fairly uncommon Passiflora with ornate flowers, quite similar to the better known Passiflora actinia (Junqueira et al., 2008). Passiflora bahiensis habits the Bahia state, being typical to intermediate climate. It is also a vine, reaching several meters in length. Passiflora coccinea, or scarlet passion flower, and Passiflora vitifolia share similarities in the intense red flower aspects, and both are native to the Amazon region (but $P$. vitifolia also occurs in Central America). With exception of $P$. quadrangularis (Zucolotto et al., 2012), there are no available scientific studies in regard to the other four species.

The purpose of this research was to analyze the phenolic composition of hydroalcoholic extracts of five Passiflora species and compare them, using for this aim high-performance liquid chromatography with diode array detection and electrospray ionization tandem mass spectrometry HPLC-DAD-ESI-MS/MS.

\section{Materials and Methods}

\section{Plant material}

The leaves of the five Passiflora species were harvested at the Plantarum Institute, located in Nova Odessa-SP, Brazil. A voucher of each species is deposited in the herbarium of the Institute under the following numbers: $P$. bahiensis Klotzsch, $\mathrm{H}$. Lorenzi 6031, (HPL), 6447, 2006; P. coccinea Aubl., H. Lorenzi 2869 (HPL) 6287, 2001; P. quadrangularis L., A. Campos-Rocha 504, (HPL) 11832; P. sidifolia, L.C. Bernacci \& R. Tsuji 4463, (HPL) 11003, 2008; P. vitifolia Kunth, L.C. Bernacci, H. Lorenzi et al., 4149, (HPL) 7434, 2006.

Apigenin, vitexin, orientin, rutin, quercetin and luteolin were purchased from Sigma-Aldrich Chemical CO. (St. Louis, MO, USA), and their purities were above 97\%, as determined by HPLC/DAD analysis. Stock solutions of these compounds (1 mg/ $\mathrm{mL})$ were prepared in ethanol. HPLC grade methanol was purchased from Merck (Darmstadt, Germany). Deionized water was prepared from distilled water using a Milli-Q system (Millipore, Waters, Milford, MA, USA).

Assays

\section{Extraction}

Fresh aerial parts of the five species were airdried in the shade at room temperature to a constant weight, ground to pass through a 30 mesh screen, and stored in sealed glass vials. For preparation of the lyophilized extracts, $100 \mathrm{~g}$ of powder was extracted with 1 L hydroethanolic solution $50 \%(\mathrm{v} / \mathrm{v})$ by turboextraction (Mendes et al., 2002). The crude preparation was filtered through Whatman paper $n^{\circ} 1$ and concentrated under reduced pressure in a rotaevaporator to produce a crude extract, which was placed in a lyophilizer (4 atm of pressure and temperature of $40^{\circ} \mathrm{C}$ ) for $48 \mathrm{~h}$. The lyophilized extracts were stored in amber flasks at $5{ }^{\circ} \mathrm{C}$ (freezer).

HPLC-DAD-ESI-MS/MS analysis of these hydroethanolic extracts

For the reversed phase high performance liquid chromatography (RPHPLC) analysis, lyophilized extracts were dissolved in water:methanol $(80: 20) \mathrm{v} / \mathrm{v}$ in the concentration $10 \mathrm{mg} / 3 \mathrm{~mL}$ and filtered with a 0.45 $\mu \mathrm{m}$ filter prior to injection of $30.0 \mu \mathrm{L}$ (concentration of $50 \mu \mathrm{g} / \mathrm{mL}$ ) into the HPLC system. Spectral UV data 
from all peaks were collected in the range $240-400 \mathrm{~nm}$, and chromatograms were recorded at 360 and $270 \mathrm{~nm}$ for phenolic compounds. The HPLC-DAD-ESI-MS system consisted of an DADSPD-M10AVP Shimadzu equipped with a photodiode array detector coupled to Esquire 3000 Plus, Bruker Daltonics quadrupole. The mass detector was a quadrupole ion trap equipped with atmospheric pressure ionization source through electrospray ionization interface. All the operations, acquisition and data analysis were controlled by SCL10A VP software. The mobile phases consisted of eluent A ( $0.1 \%$ aq. formic acid) and eluent B (methanol), and the gradient profile was: $0 \mathrm{~min}-20 \% \mathrm{~B}$ in $\mathrm{A} ; 10 \mathrm{~min}$ - $30 \% \mathrm{~B}$ in $\mathrm{A}, 20 \mathrm{~min}-50 \% \mathrm{~B}$ in $\mathrm{A} ; 30 \mathrm{~min}-70 \%$ $\mathrm{B}$ in $\mathrm{A} ; 40 \mathrm{~min}-90 \% \mathrm{~B}$ in $\mathrm{A} ; 45 \mathrm{~min}-40 \% \mathrm{~B}$ in $\mathrm{A}$ and finally returned to the initial conditions $(20 \%$ $\mathrm{B})$ to re-equilibrate the column prior to another run, using a reverse phase, C18, Zorbax-5B-RP-18 (Hewlett Packard) column $(4.6 \times 250 \mathrm{~mm}, 5 \mu \mathrm{m})$, connected to a guard column. The flow rate was kept constant at $0.5 \mathrm{~mL} \mathrm{~min}^{-1}$, and the temperature of the column was maintained at $28{ }^{\circ} \mathrm{C}$. The ionization conditions were adjusted as follows: electrospray voltage of the ion source $-40 \mathrm{~V}$, a capillary voltage $4500 \mathrm{~V}$ and a capillary temperature of $325{ }^{\circ} \mathrm{C}$. Helium $(\mathrm{He})$ was used as the collision gas and nitrogen $\left(\mathrm{N}_{2}\right)$ as the nebulizing gas. Nebulization was aided with a coaxial nitrogen sheath gas provided at a pressure of 27 psi. Desolvation was facilitated using a counter current nitrogen flow set at a flux of $7.0 \mathrm{~L} / \mathrm{min}$. The full scan mass acquisition both in negative and positive ion mode were performed by scanning from 100 up to $1200 \mathrm{~m} / z$ range. Collision Induced Dissociation (CID) spectra were performed in the ion trap using helium as collision gas, with voltage ramping cycles from 0.5 up to $1.3 \mathrm{~V}$. Double on-line detection was made by a photodiode spectrophotometer and mass spectrometry. A data-dependent program was used so that the most abundant ions in each scan were selected and subjected to MS/MS analysis. The constituents were identified by ion-trap mass spectrometry in both positive and negative ion modes and the structures were proposed based mainly on the MS/MS fragmentation data conjugated with the UVDAD spectral and literature data.

\section{Results and Discussion}

The classes of compounds were recognizable from their characteristic UV spectra, which were identifiable based on the LC-MS/MS data and subsequent confirmation by comparison with literature data. The chromatographic and spectroscopic data are summarized in Tables 1 to 5. On-line UV-visible spectra of the flavones exhibited two major absorption bands in the UV region: band I absorption occurring in the 330-
$340 \mathrm{~nm}$ range and band II in the $260-272 \mathrm{~nm}$ range. Tandem Mass spectrometry is one of the most sensitive methods for molecular analysis and much useful for distinguishing compounds with identical molar mass (Ferreres et al., 2007; Abad-Garcia et al., 2008, 2009).

In flavonoids glycosides, glucose is the most common sugar, galactose, rhamnose, xylose, glucuronic acid and arabinose are common and mannose, fructose and galacturonic acid are rare. The distinction among flavones $C$-glycosides and flavonols $O$-glycosides was based on MS/MS fragmentation behavior. Flavonoid $O$-glycosides are bounded to a sugar with formation of an acid labile glycosidic $O-C$ bond. Fragmentation of these flavonoids involves the cleavage at the glycosidic $O$-linkage with a concomitant H-rearrangement leading to the elimination of the saccharide residue (Ferreres et al., 2007; Figueirinha et al., 2008; AbadGarcia et al., 2008, 2009). Glycosylation also occurs by direct linkage of the sugar to the basic nucleus of the flavonoid, which is stable towards acid hydrolysis, to form flavonoid $C$-glycosides. Fragmentation of flavonoid $C$-glycosides needs higher collision energies than $O$-glycosides, and the main fragmentations take place in the sugar, which possesses the weakest bonds. Thus, in $C$-glycosylflavones, the main fragments are related to cross-ring cleavages in the sugar units, the more extensive fragmentation being for the C-6 sugar residue (Ferreres et al., 2007; Figueirinha et al., 2008; Abad-Garcia et al., 2008, 2009).

Both positive and negative ion modes were used in analyses of these species because they provide complementary structural information. The tandem mass spectrometry fragmentation pathways obtained for these flavonoids glycosides were consistent with literature reports. Flavones glycosides were found in the extracts of the five species. P. quadrangulares exhibited a high content of cyclopassiflosides (saponins), $P$. coccinea exhibited procyanidins, while in P. bahiensis was found one caffeoylquinic derivative and in $P$. sidifolia one rosmarinic acid derivative. Cyanogenic glycosides were found in P. quadrangularis and P. bahiensis. Such results can be seen in Tables 1-5. A detailed look at each species can be found below.

\section{Passiflora sidifolia}

Flavonoid $C$-glycosides are divided into mono- $C$-glycosyl, di- $C$-glycosyl- and $O, C$-diglycosylflavonoids, in which a hydrolyzable sugar is linked either to a phenolic hydroxyl group or a hydroxyl group of the $C$-glycosyl residue (Abad-Garcia et al., 2008, 2009). In this species were found $C, O$-diglycosides, di- $C$-glycosides and mono- $C$-glycosides flavones, with exception of compound $\mathbf{1}$ at $5.1 \mathrm{~min}$, that showed a UV spectrum characteristic of caffeoyl derivatives, with 
maximum absorption at $320 \mathrm{~nm}$. The ESI-MS spectrum exhibited a deprotonated molecule at $\mathrm{m} / z$ 682.8. The MS/MS spectrum of deprotonated molecule at $m / z 682.8$ fragmented to give fragments at $\mathrm{m} / \mathrm{z} 520.8$, indicating the loss of a glucose moiety, a base peak at $\mathrm{m} / \mathrm{z} 340.8$ (caffeic acid+hexoside-H) indicating the presence of a caffeoyl hexoside moiety and another fragment at $\mathrm{m} / \mathrm{z}$ 178.7, which corresponds to a deprotonated caffeic acid moiety. The MS/MS spectrum on precursor ion at $\mathrm{m} / \mathrm{z} 340.8$ produced a fragment at $\mathrm{m} / \mathrm{z} 178.7(100 \%)$ (deprotonated caffeic acid) (Table 1). The hexoside group probably was linked to caffeoyl moiety, since a base peak was observed at $\mathrm{m} / z 340.8$ (Gouveia \& Castilho, 2011; Negri et al., 2011). Compound 1 was characterized as a rosmarinic acid diglucoside, which was also found in bee pollen samples (Negri et al., 2011).

Compounds 2 to 9 exhibited UV spectral data typical of flavones glycosides. The ESI-MS spectra of compound 2 at $17.9 \mathrm{~min}$ (Table 1) exhibited protonated and deprotonated molecules at $\mathrm{m} / \mathrm{z} 595.3$ and 593.1 and $[\mathrm{M}+\mathrm{Na}]^{+}$at $m / z$ 617.2, respectively. Its $\mathrm{MS} / \mathrm{MS}$ spectrum in negative ion mode produced ions at $\mathrm{m} / \mathrm{z}$ 575.1 (M-H-18)', m/z 503.0 (M-H-90)-, and a base peak at 473.1 (M-H-120)', exhibiting a fragmentation pattern of flavones di- $C$-glycoside (Table 1$)$. The ions

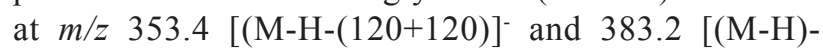
$(90+120)]$ - indicated the presence of apigenin (MW 270) as aglycone and two hexose moieties (glucoses). The MS/MS data obtained in positive ion mode $(\mathrm{m} / \mathrm{z}$ 595.3) are placed in Table 3. Comparing with MS literature data (Piccinelli et al., 2008), this compound was characterized as 6,8-di- $C$-glucosylapigenin, also known as vicenin-2. No commercial standard of vicenin-2 are available, therefore, this peak was compared with vicenin-2, present in P. incarnata extract, used as a surrogate standard (Negri et al., 2012).

For compound 3 at $18.7 \mathrm{~min}$, ESI-MS spectrum gave a deprotonated molecule at $\mathrm{m} / \mathrm{z}$ 431.1. The MS/MS spectrum of deprotonated molecule yielded a base peak at $m / z 384.8$, by losing of $46 \mathrm{u}$, which was probably obtained through a decarboxylation of a glucuronic acid moiety at the terminal position. This compound probably possesses pinocembrim as aglycone, and was tentatively characterized as pinocembrin glucuronide.

The ESI-MS spectrum for compound $\mathbf{4}$ at 19.5 min exhibited a deprotonated molecule at $\mathrm{m} / \mathrm{z}$ 593.0. The carbon-carbon bond is resistant to cleavage, thus in flavones $C$-glycosides the main cleavage are at the bonds of the sugar (Abad-Garcia et al., 2008, 2009). The MS/MS spectrum of deprotonated molecule gave fragments at $\mathrm{m} / z 502.9$ [M-H-90] $(40 \%)$, indicating the presence of deoxyhexose, a base peak at $\mathrm{m} / \mathrm{z} 472.8$ [M-H-120] indicating the presence of hexose, and a fragment at $\mathrm{m} / \mathrm{z} 326.7$ (aglycone+41) indicating luteolin as aglycone (Table 1). Deprotonated molecules dissociated in collision induced dissociation (CID) produced fragments, typical offlavones- $C, O$-glycosides, which are indicated by ions $\mathrm{Ag}+41 / \mathrm{Ag}+71$ (Ferreres et al., 2007). The irregular ion at $m / z 446.8$ (Table 1) can be rationalized by the loss of an internal rhamnose residue. Compound $\mathbf{4}$ was tentatively characterized as orientin-2"-O-rhamnoside.

For compound $\mathbf{5}$ at $20.5 \mathrm{~min}$, the ESI-MS spectrum exhibited a deprotonated molecule at $\mathrm{m} / \mathrm{z}$ 447.1. The MS/MS spectrum on precursor ion at $\mathrm{m} / \mathrm{z}$ 447.1 exhibited fragments ions at $\mathrm{m} / \mathrm{z} 356.9$ (M-H-90) and a base peak at $m / z 326.9$ (M-H-120) (Table 1). For flavones mono- $C$-hexosides, the position of the sugar residue can be assigned through observation of the abundance of fragment ion (M-H-18)- In general, the fragmentation of the 6 - $C$-isomers is more extensive, giving a ion corresponding to (M-H-18) ${ }^{-}$, probably due to the formation of an additional hydrogen bond between the 2"-hydroxyl group of the sugar and the 5- or 7-hydroxyl group of the aglycone, which confers additional rigidity (Abad-Garcia et al., 2008, 2009; Figueirinha et al., 2008). For this compound, the abundance of fragment ion at $\mathrm{m} / \mathrm{z} 428.8$ (20) suggested that the mono- $C$-glycosylation is in position 6 , being identified as luteolin-6- $C$-glucoside, also known as isoorientin.

The ESI-MS spectrum for compound $\mathbf{6}$ at 21.7 min also exhibited a deprotonated molecule at $\mathrm{m} / \mathrm{z}$ 593.0. The MS/MS spectrum of deprotonated molecule at $\mathrm{m} / \mathrm{z} 593.0$ gave a base peak at $\mathrm{m} / z 412.8(\mathrm{M}-\mathrm{H}-$ 180 ), and a fragment ion at $\mathrm{m} / \mathrm{z} 293.0$ (aglycon+4118) (Table 1) that correspond to apigenin as aglycone. The loss of $180 \mathrm{u}(162+18)$ resulting in a base peak is characteristic of an $O$-glycosilation on the hydroxyl group on the position 2" of the $C$-glycosylation sugar in $C$-glycosyl derivatives $O$-glycosylated (Ferreres et al., 2007). The loss of $120 \mathrm{u}$ indicated the presence of hexose as $C$-glycosylation sugar. Compound $\mathbf{6}$ was tentatively characterized as vitexin-2"-O-glucoside.

For compound 7 at $22.3 \mathrm{~min}$, the ESI-MS spectrum exhibited a deprotonated molecule at $\mathrm{m} / \mathrm{z}$ 563.0 , and the MS/MS spectrum of deprotonated molecule at $\mathrm{m} / \mathrm{z} 563.0$ yielded a base peak at $\mathrm{m} / \mathrm{z} 412.7$ (M-H-150), indicating the presence of pentose as a sugar moiety and also a fragment ion at $\mathrm{m} / \mathrm{z} 293.0$ (aglycone $+41-18)^{-}$also indicating apigenin as aglycone. The loss of sugar in addition to water $(132+18)$ is characteristic of a bond among a pentose and a nonphenolic hydroxyl group, probably at the 2"-O-position, indicating that xylose is linked to glucosyl moiety. This flavone was characterized as vitexin-2"- $O$-xyloside, a known constituent of Passiflora species (Wohlmut et al., 2010). Compound 8 at $22.8 \mathrm{~min}$, in which the ESI-MS spectrum gave a deprotonated molecule at $\mathrm{m} / \mathrm{z}$ 
431.2 was characterized as 8 - $C$-glucosyl apigenin, also known as vitexin. Its MS/MS data in negative ion mode are presented in Table 1. Vitexin is a one of the main constituent of some Passiflora species (Grundmann et al., 2008; Negri et al., 2012).

The main constituent found in this hydroethanolic extract, compound 9 at $24.6 \mathrm{~min}$, is probably a flavone- 6,8 -di- $C$-glycoside. The ESI-MS spectrum exhibited a deprotonated molecule at $\mathrm{m} / \mathrm{z}$ 547.0, which was further fragmented giving fragments at $m / z 528.5(\mathrm{M}-\mathrm{H}-18)^{-}$, at $\mathrm{m} / \mathrm{z} 486.8\left(\mathrm{M}-\mathrm{H}-60^{-}\right.$, indicating the presence of a $C$-pentose unit, probably arabinose and a base peak at $m / z 456.9$ (M-H-90) indicating the presence of deoxyhexose (rhamnose). The sugar substituent linked at C6 position of aglycone gives the most intense fragment (Figueirinha et al., 2008; Liu et al., 2009, 2011). The (M-H-90)- (Table $1)$ is much more intense than the (M-H-60)- ion, thus indicating that the deoxyhexose is located at C6, while that the pentose is located at C8. Comparing with MS literature data (Liu et al., 2009, 2011), this compound was tentatively characterized as apigenin-6$C$-rhamnosyl-8-C-arabinoside.

Table 1. Flavones glycosides found in hydroethanolic extract of Passiflora sidifolia.

\begin{tabular}{|c|c|c|c|c|c|}
\hline Compound & $\begin{array}{l}\mathrm{RT} \\
(\mathrm{min})\end{array}$ & $\begin{array}{l}\mathrm{UV} \lambda_{\max } \\
(\mathrm{nm})\end{array}$ & $\begin{array}{c}(\mathrm{ESI})^{-} \\
(\mathrm{m} / z \text { abundance })\end{array}$ & Proposed structure & References \\
\hline 1 & 5.1 & 320 & $\begin{array}{l}\text { MS: 683.0; MS/MS: } 520.8 \text { (60), } 340.8 \text { (100), } \\
\text { 179.1 (50) }\end{array}$ & $\begin{array}{l}\text { rosmarinic acid } \\
\text { diglucoside }\end{array}$ & $\begin{array}{l}\text { Gouveia \& Castilho, 2011; } \\
\text { Negri et al., } 2011\end{array}$ \\
\hline 2 & 17.9 & 270,340 & $\begin{array}{l}\text { MS: 593.1; MS/MS: } 574.9(20), 502.8(20) \text {, } \\
472.8(100), 382.8(20), 352.7(20) .\end{array}$ & vicenin-2 & $\begin{array}{c}\text { Piccinelli et al., 2008; Negri } \\
\text { et al., } 2012\end{array}$ \\
\hline 3 & 18.7 & ND & MS: 431.1; MS/MS: 384.8 (100) & pinocembrin glucuronide & \\
\hline 4 & 19.5 & 270,340 & $\begin{array}{l}\text { MS: 593.0; MS/MS: } 502.9(40), 472.8(100) \text {, } \\
446.8(20), 326.7(50)\end{array}$ & $\begin{array}{l}\text { orientin-2"-O- } \\
\text { rhamnoside }\end{array}$ & Ferreres et al., 2007 \\
\hline 5 & 20.5 & 270,350 & $\begin{array}{l}\text { MS: 447.1; MS/MS: } 428.8(20), 356.9(70) \text {, } \\
326.9(100)\end{array}$ & isoorientin & $\begin{array}{l}\text { Abad-Garcia et al., 2008; } \\
\text { Figueirinha et al., } 2008\end{array}$ \\
\hline 6 & 21.7 & 270,340 & MS: 593.0; MS/MS: 412.8 (100), 293.0 (30) & vitexin-2"-O-glucoside & Ferreres et al., 2007 \\
\hline 7 & 22.3 & 270,340 & MS: 563.0; MS/MS: 412.7 (100), 293.0 (30) & vitexin-2"- $O$-xyloside & Wohlmuth et al., 2010 \\
\hline 8 & 22.8 & 270,340 & MS: 431.2; MS/MS: $340.7(50), 310.7$ (100) & vitexin & Grundman et al., 2008 \\
\hline 9 & 24.6 & 270,340 & $\begin{array}{l}\text { MS: 547.0; MS/MS: } 528.9(20), 486.8(70) \text {, } \\
456.9(100)\end{array}$ & $\begin{array}{l}\text { apigenin-6- } C \text {-rhamnosyl- } \\
8 \text { - } C \text {-arabinoside }\end{array}$ & $\begin{array}{l}\text { Liu et al., 2009, 2011; } \\
\text { Figueirinha et al., } 2008\end{array}$ \\
\hline
\end{tabular}<smiles>O=C(/C=C/c1ccc(O)c(O)c1)OC(Cc1ccc(O)c(O)c1)C(=O)O</smiles><smiles>O=C1C[C@H](c2ccccc2)Oc2cc(OC(O)C(O)C3C(O)C(O)C(CO)C3O)cc(O)c21</smiles>

3<smiles>[R3]c1ccc(-c2cc(=O)c3c(O)c([R3])c(O)c([R])c3o2)cc1O</smiles>

$5 \mathrm{R}_{1}=\mathrm{OH} ; \mathrm{R}_{2}=\mathrm{H} ; \mathrm{R}_{3}=\mathrm{Glc}$ $8 \mathrm{R}_{1}=\mathrm{R}_{2} \mathrm{H} ; \mathrm{R}_{3}=\mathrm{GlC}$

$9 \mathrm{R}_{1}=\mathrm{H} ; \mathrm{R}_{2}=\mathrm{Rham} ; \mathrm{R}_{3}=$ Ara

$20 \mathrm{R}_{1}=\mathrm{OH} ; \mathrm{R}_{1}=\mathrm{R}_{2}=\mathrm{Glc}$

$23 \mathrm{R}_{1}=\mathrm{OH} ; \mathrm{R}_{2}=\mathrm{Glc} ; \mathrm{R}_{3}=\mathrm{H}$

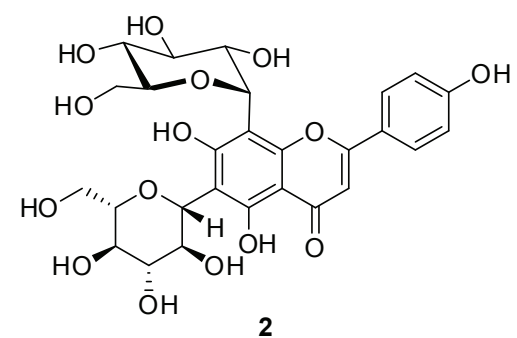

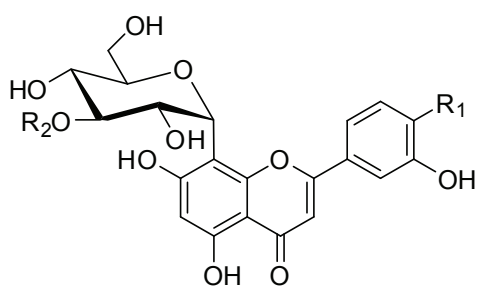

$4 \mathrm{R}_{1}=\mathrm{OH} ; \mathrm{R}_{2}=\mathrm{Rham}$

$6 \mathrm{R}_{1}=\mathrm{H} ; \mathrm{R}_{2}=\mathrm{GlC}$

$7 \mathrm{R}_{1}=\mathrm{H} ; \mathrm{R}_{2}=\mathrm{Xyl}$

$10 \mathrm{R}_{1}=\mathrm{OH} ; \mathrm{R}_{2}=\mathrm{Xyl}$ 


\section{Passiflora quadrangularis}

In $P$. quadrangularis were found flavones $C, O$ diglycosides, saponins (cyclopassifloside derivatives) and cyanogenic glycosides. Two of the flavones $C, O$ diglycosides found in this hydroethanolic extract, compounds 6 and 7, were also found in P. sidifolia. Another $C$-glycosyl flavone $O$-glycosilated on the sugar moiety of the $C$-glycosylation was found at $20.9 \mathrm{~min}$. Compound 10 exhibited a protonated, deprotonated and sodiated molecule at $\mathrm{m} / \mathrm{z} 581.1,578.9$ and 603.1 respectively. The MS/MS spectrum of deprotonated molecule at $m / z 578.9$ gave fragments ions at $\mathrm{m} / \mathrm{z} 458$. References 7 (M-H-120), at $\mathrm{m} / \mathrm{z} 428.7(\mathrm{M}-\mathrm{H}-150)^{-}$, at $\mathrm{m} / \mathrm{z} 356.9{\text { (aglycone }+71)^{-} \text {and }}^{-}$ a base peak at $\mathrm{m} / \mathrm{z} 326.8$ (aglycone +41$)^{-}$, indicating the presence of a pentose (xylose) and a hexose (glucose) as sugar moieties and luteolin as aglycone (Table 2). Based on comparison with literature data (Ferreres et al., 2007), compound $\mathbf{1 0}$ was assigned as orientin-2"-Oxyloside. Although isoorientin and isovitexin were found as principal constituents in leaves of this species by Antognoni et al. (2007), these flavones were not detected in this hidroalcoholic extract. There are few reports about the flavonoids composition of $P$. quadrangularis. Vitexin2"-O-rhamnoside was characterized as minor constituent by Zucolotto et al. (2012).

Cycloartane triterpenes, such as cyclopassifloic acids and their saponins derivatives cyclopassiflosides, has been isolated from Passiflora genus (Yoshikawa et al., 2000a,b). Saponins, cyclopassifloside possessing a cyclopassifloic acid B or D as aglycone, were found in high content in this specie. Detection of saponins using UV is difficult, due to their exhibit poor absorption. Cyclopassiflosides were detected only in the chromatogram obtained using ESI-MS. The foam formation during extraction and solvent evaporation was an evidence for the presence of saponins.

Ciclopassifloic acid B exhibits molecular formula $\mathrm{C}_{31} \mathrm{O}_{6} \mathrm{H}_{52}$ and molar mass $520 \mathrm{u}$. The ESI-MS spectrum of cyclopassifloside 15 at Rt 37.2 min gave a deprotonated molecule at $\mathrm{m} / \mathrm{z}$ 843.3. A predominant ion at $m / z 797.0$ was yielded by the loss of a neutral residue with $46 \mathrm{u}$ from deprotonated molecule at $\mathrm{m} / z$ 843.3, which probably was obtained through a decarboxilation, loss of $\left(\mathrm{COOH}_{2}\right)$ from cyclopassifloic acid B. Cyclopassifloside $\mathbf{1 5}$ was tentatively characterized as cyclopassifloside III $[1-O-(1 \alpha, 3 \beta, 9 \beta, 24 \mathrm{~S})-24-(\beta-\mathrm{D}-$ glucopyranosyloxy)methyl-1,3,24-trihydroxy-28-oxo9,19-cyclolanosten-28-yl)- $\beta$-D-glucopyranose], being probably formed by a cyclopassifloic acid B (aglycone) and two hexoses (glucoses) as sugar moieties, a $\beta$ glucose group and an ester linked $\beta$ glucosyl group. Cyclopassifloside III was also reported in P. edulis by Yoshikawa et al. (2000a). The ESI-MS of compound 14 at $36.9 \mathrm{~min}$ gave a deprotonated molecule at $\mathrm{m} / \mathrm{z}$
989.4, which correspond to 146 mass units greater than cyclopassifloside III (15). A predominant ion at $\mathrm{m} / \mathrm{z} 943.3$, which was also yielded by the loss of 46 $\mathrm{u}$ from deprotonated molecule at $\mathrm{m} / \mathrm{z} 989.4$ (Table 2), suggested that cyclopassifloside $\mathbf{1 4}$ is also formed by cyclopassifloic acid B with more three hexoses (two glucoses and one rhamnose), being tentatively characterized as cyclopassifloside III rhamnoside.

Ciclopassifloic acid D possesses $\mathrm{C}_{30} \mathrm{O}_{6} \mathrm{H}_{48}$ as molecular formula and molar mass of $504 \mathrm{u}$. For compound $\mathbf{1 3}$ at $36.3 \mathrm{~min}$, ESI-MS spectra exhibited a deprotonated, protonated and sodiated molecule at $\mathrm{m} / \mathrm{z}$ 959.2, $\mathrm{m} / \mathrm{z} 961.0$ and $\mathrm{m} / \mathrm{z}$ 983.0, respectively. The MS/ MS spectrum showed a base peak at $\mathrm{m} / \mathrm{z}$ 797.0, which corresponded to the loss of glucose moiety $(162 \mathrm{u})$ from deprotonated molecule at $m / z$ 959.2 (Table 2), suggesting the existence of a glucose group. Cyclopassifloside $\mathbf{1 3}$ probably was formed by ciclopassifloic acid D as aglycone with more two glucoses and a pentose, probably, arabinose as sugar moieties, being tentatively characterized as cyclopassifloic acid D arabinosyl diglucoside.

The ESI-MS spectra for compound $\mathbf{1 6}$ at 37.8 min (Table 2) exhibited a deprotonated, protonated and sodiated molecule at $\mathrm{m} / \mathrm{z} 943.3, \mathrm{~m} / \mathrm{z} 945.0$ and at $\mathrm{m} / \mathrm{z}$ 967.0, respectively. Cyclopassifloside $\mathbf{1 6}$ underwent similar fragmentation as cyclopassifloside 13, eliminating a hexose residue from deprotonated molecule at $\mathrm{m} / \mathrm{z} 943.3$ to produce a base peak at $\mathrm{m} / \mathrm{z}$ 781.0. Cyclopassifloside 16 was also probably formed by cyclopassifloic acid D as aglycone, having glucose, rhamnose and arabinose as sugar moieties, and was tentatively characterized as cyclopassifloic acid D glucosyl rhamnosyl arabinoside. For compound $\mathbf{1 8}$ at $39.4 \mathrm{~min}$ the ESI-MS spectrum also showed a deprotonated molecule at $\mathrm{m} / \mathrm{z} 843.3$ and the MS/MS spectrum showed the same fragmentation pattern than compound $\mathbf{1 5}$, the similarity in structure results from their similar fragmentation pathways, being tentatively characterized as a cyclopassifloside III isomer.

For cyclopassifloside 19 at Rt $40.8 \mathrm{~min}$, the ESI-MS spectrum exhibited a deprotonated molecule at $\mathrm{m} / \mathrm{z} 827.0$ suggesting 828.0 as molar mass (Table 2). Cyclopassifloside 19 is probably formed by cyclopassifloic acid B as aglycone esterified with a glucosyl and rhamnosyl groups, being tentatively identified as cyclopassifloic acid B rhamnosyl glucoside. So far, much of this cyclopassifloside is being reported for the first time. In the MS/MS fragmentation in negative ion mode, a loss of glucose was observed in cyclopassiflosides containing a cyclopassifloic acid D as aglycone, while that the loss of $46 \mathrm{u}$, a carboxylic group, was observed in cyclopassifloside that contain cyclopassifloic acid B as aglycone.

Quadranguloside was reported in $P$. alata by Reginatto et al. (2004) and in P. quadrangularis 
by Orsini et al. (1986, 1987). Quadranguloside possess molecular formula $\mathrm{C}_{54} \mathrm{O}_{23} \mathrm{H}_{90}$ and molar mass $1106 \mathrm{u}$. For quadranguloside, the aglycone moiety (9,19-cyclolanost-24Z-en-3 $\beta, 21,26$-triol) possesses molecular formula $\mathrm{C}_{30} \mathrm{O}_{3} \mathrm{H}_{50}$ and molar mass $458 \mathrm{u}$, and the sugar moieties are two gentiobiosides. The ESI-MS spectrum of cyclopassifloside $\mathbf{1 7}$ at $38.2 \mathrm{~min}$ exhibited a deprotonated molecule at $\mathrm{m} / \mathrm{z} 1105.1$ (Table 2) and was tentatively characterized as quadranguloside.

Cyanogenesis is widespread in plants, but relatively few cyanogenic compounds have been isolated and characterized. In the hydroethanolic extract of $P$. quadrangularis two cyanogenic glycosides were also found. Molecules bearing a positive charge, such as cyanogenic glycosides, ionize best with positive ion ESI (Sendker \& Nahrstedt, 2010). Compound $\mathbf{1 1}$ at 32.4 min exhibited a protonated molecule at $\mathrm{m} / \mathrm{z} 304.1$ and the molar mass was deduced as 303.1u. Passiguatemalin [1-( $\beta$-D-glucopyranosyloxy)-2,3-dihydroxycyclopentene1-carbonitrile] that possess molecular formula $\mathrm{C}_{12} \mathrm{O}_{8} \mathrm{H}_{19} \mathrm{~N}$ and molar mass $305 \mathrm{u}$ was isolated from $P$. guatemalensis (Jaroszewski et al., 2002). Compound 11 exhibiting a protonated molecule at $\mathrm{m} / \mathrm{z} 304.1$ probably is a passiguatemalin derivative with one unsaturation in cyclopentene ring, such as occur in gynocardin, a cyclopentene reported from $P$. incarnata (Jaroszewski et

Table 2. Constituents found in hydroethanolic extract of Passiflora quadrangularis.

\begin{tabular}{|c|c|c|c|c|c|c|}
\hline Compound & $\begin{array}{l}\mathrm{RT} \\
(\mathrm{min})\end{array}$ & $\begin{array}{l}\mathrm{UV} \lambda_{\max } \\
\quad(\mathrm{nm})\end{array}$ & $\begin{array}{c}(\mathrm{ESI})^{+} \\
(\mathrm{m} / z \text { abundance })\end{array}$ & $\begin{array}{c}\left(\mathrm{ESI}^{-}\right. \\
(\mathrm{m} / z \text { abundance })\end{array}$ & Proposed structure & References \\
\hline 10 & 20.9 & 270,350 & $\begin{array}{l}\text { MS: }(\mathrm{M}+\mathrm{H})^{+} 581.1 \\
(\mathrm{M}+\mathrm{Na})^{+} 603.1\end{array}$ & $\begin{array}{l}\text { MS: } 578.9 ; \text { MS/MS: } \\
458.7(60), 428.7(70), \\
356.7(50), 326.8(100)\end{array}$ & orientin-2"-O-xyloside & Ferreres et al., 2007 \\
\hline 6 & 21.7 & 270,340 & $\begin{array}{l}\text { MS: }(\mathrm{M}+\mathrm{H})^{+} 595.1 \\
(\mathrm{M}+\mathrm{Na})^{+} 617.0\end{array}$ & $\begin{array}{l}\text { MS: 593.0; MS/MS: } \\
412.8 \text { (100), } 293.0(30)\end{array}$ & vitexin-2"-O-glucoside & Ferreres et al., 2007 \\
\hline 7 & 22.3 & 270,340 & MS: $(\mathrm{M}+\mathrm{H})^{+} 565.1$ & $\begin{array}{l}\text { MS: 563.0; MS/MS: } \\
412.7(100), 293.0(30)\end{array}$ & vitexin-2"- $O$-xyloside & Ferreres et al., 2007 \\
\hline 11 & 32.4 & & MS: $(\mathrm{M}+\mathrm{H})^{+} 304.1$ & & gynocardin & Jaroszewski et al., 2002 \\
\hline 12 & 34.9 & & $\begin{array}{l}\text { MS: }(\mathrm{M}+\mathrm{H})^{+} 332.2 ; \\
\text { MS/MS: } 314.2(100), \\
270.2(50), 252.2(30)\end{array}$ & & dhurrinamide derivative & $\begin{array}{l}\text { Sendker \& Nahrstedt, } \\
2010\end{array}$ \\
\hline 13 & 36.3 & & $\begin{array}{l}\text { MS: }(\mathrm{M}+\mathrm{H})^{+} 961.0 \\
(\mathrm{M}+\mathrm{Na})^{+} 983.0\end{array}$ & $\begin{array}{l}\text { MS: 959.2; MS/MS: } \\
797.0(100)\end{array}$ & $\begin{array}{l}\text { cyclopassifloic acid D } \\
\text { arabinosyl-diglucoside }\end{array}$ & Yoshikawa et al., 2000a, b \\
\hline 14 & 36.9 & & & $\begin{array}{l}\text { MS: 989.4; MS/MS: } \\
943.3(100)\end{array}$ & $\begin{array}{l}\text { cyclopassifloside III } \\
\text { rhamnoside }\end{array}$ & Yoshikawa et al., 2000a, b \\
\hline 15 & 37.2 & & & $\begin{array}{l}\text { MS: 843.3; MS/MS: } \\
797.0(100)\end{array}$ & cyclopassifloside III & Yoshikawa et al., 2000a, b \\
\hline 16 & 37.8 & & $\begin{array}{l}\text { MS: }(\mathrm{M}+\mathrm{H})^{+} 945.0 \\
(\mathrm{M}+\mathrm{Na})^{+} 967.0\end{array}$ & $\begin{array}{l}\text { MS: 943.3; MS/MS: } \\
781.0(100)\end{array}$ & $\begin{array}{l}\text { cyclopassifloic acid } \\
\text { D-arabinosyl-rhamnosyl- } \\
\text { glucoside }\end{array}$ & Yoshikawa et al., 2000a, b \\
\hline 17 & 38.2 & & & MS: 1105.1 & quadranguloside & $\begin{array}{l}\text { Orsini et al., 1987, 1986; } \\
\text { Reginatto et al., } 2004\end{array}$ \\
\hline 18 & 39.4 & & & $\begin{array}{l}\text { MS: 843.3; MS/MS: } \\
797.0(100)\end{array}$ & cyclopassifloside III isomer & Yoshikawa et al., 2000a, b \\
\hline 19 & 40.8 & & & MS: 827.0 & $\begin{array}{l}\text { cyclopassifloic acid B } \\
\text { rhamnosyl glucoside }\end{array}$ & Yoshikawa et al., 2000a, b \\
\hline
\end{tabular}<smiles>N#C[C@]1(OCl)C=CC(O)C1O</smiles>

11<smiles>CC(Cl)(OC(Cl)C(N)=O)c1ccc(O)cc1</smiles>

12

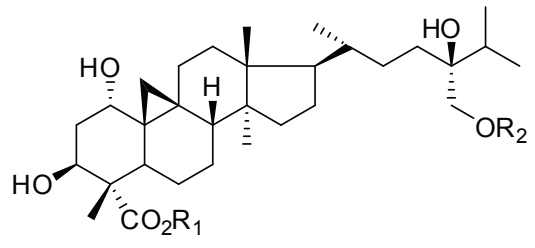

$14 R_{1}=$ glucosylrhamnoside; $R_{2}=G l c$

$15 \mathrm{R}_{1}=\mathrm{R}_{2}=\mathrm{GlC}$

$19 \mathrm{R}_{1}=$ Rham; $\mathrm{R}_{2}=\mathrm{Glc}$ 


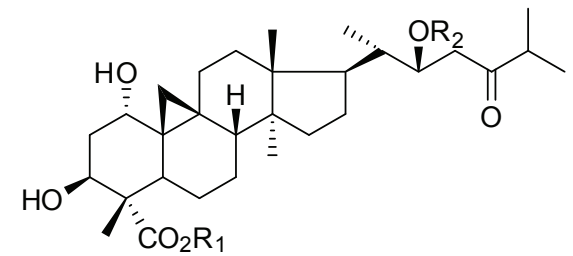

$13 \mathrm{R}_{1}=$ diglucoside; $\mathrm{R}_{2}=$ Ara

$16 \mathrm{R}_{1}=$ rhamnosylarabinoside; $\mathrm{R}_{2}=\mathrm{Glc}$

al., 2002). Thus, this cyanogenic glycoside was tentatively characterized as gynocardin.

For some cyanogenic plants, primary amide glucosides have been detected, whose structures correspond to the respective cyanogenic glycoside, in that the nitrile moiety has been converted into a primary carboxamide group. These amides were exclusively found in air-dried leaves whereas fresh material of the same plants do not yield detectable amounts of amides, only a cyanogenic glycoside (Jaroszewski et al., 2002; Sendker \& Nahrstedt, 2010). The cyanogenic amide glycoside $\mathbf{1 2}$ at Rt $34.9 \mathrm{~min}$ exhibited protonated molecule at $\mathrm{m} / \mathrm{z}$ 332.3. Dhurrin (4-hydroxymandelamide glucoside) is a prunasin derivative with an extra hydroxyl group on benzoyl group (Seigler et al., 2005). According to Sendker \& Nahrstedt (2010), dhurrinamide exhibited a protonated molecule in HR-ESI-MS at $\mathrm{m} / z$ 330.1180, possessing the molecular formula $\mathrm{C} 14 \mathrm{H} 19 \mathrm{NO} 8$. Prunasinamide exhibited a protonated molecule in HR-ESI-MS at $\mathrm{m} / \mathrm{z}$ 314.1232, possessing the molecular formula $\mathrm{C}_{14} \mathrm{H}_{19} \mathrm{NO}_{7}$. For compound 12, the MS/MS spectrum of protonated molecule at $\mathrm{m} / \mathrm{z} 332.3$ showed a base peak at $\mathrm{m} / \mathrm{z} 314.2$ $(\mathrm{M}+\mathrm{H}-18)^{+}$, and a fragment ion at $\mathrm{m} / z 270.2$ that correspond to the loss of $\left(\mathrm{CONH}_{2}\right)$ group $(44 \mathrm{u})$ from fragment at $\mathrm{m} / \mathrm{z} 314.2$ and at $\mathrm{m} / \mathrm{z} 252.2$ that correspond to the loss of water from fragment at $\mathrm{m} / \mathrm{z} 270.0$ (Table 2). Compound $\mathbf{1 2}$ was tentatively characterized as dhurrinamide derivative.

\section{Passiflora bahiensis}

In the hydroethanolic extract from $P$. bahiensis were found flavones 6,8 -di- $C$-glycosides, flavones8,7-di-C, $O$-glycosides, one feruloylquinic acid derivative and one cyanogenic glycoside. Compound 24 at 23.5 min showed UV spectrum characteristic of feruloylquinic acid derivative, showing UV maximum absorption at 300-330 nm. The ESI-MS spectra for compound 24 showed a protonated, sodiated and deprotonated molecule at $\mathrm{m} / \mathrm{z} 693.2, \mathrm{~m} / \mathrm{z} 715.2$ and at $m / z$ 691.1, respectively (Table 3 ). The MS/MS spectrum on precursor ion at $m / z 691.1$ showed fragments ions at $\mathrm{m} / \mathrm{z} 658.9$, corresponding to the loss of methoxyl group

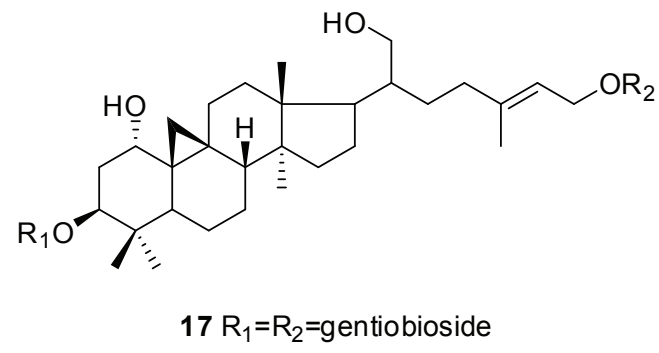

from deprotonated molecule at $\mathrm{m} / \mathrm{z} 691.1$, at $\mathrm{m} / \mathrm{z} 630.9$, correspond to the loss of $28 \mathrm{u}$ (carbonyl group) from fragment at $\mathrm{m} / \mathrm{z} 658.7$ and at $\mathrm{m} / \mathrm{z} 334.6$, corresponding to the loss of two hexoses ( $324 \mathrm{u}$ ) also from fragment at $\mathrm{m} / \mathrm{z}$ 658.9. This compound was tentatively characterized as feruloylquinic acid diglucoside.

The peaks at 16.2, 17.4, 17.9, 19.8 and 20.3 min showed a UV spectrum characteristic of flavones. Compound 2 at 17.9 min (vicenin-2) was also found in P. sidifolia. For compound $\mathbf{2 0}$ at $16.2 \mathrm{~min}$, the ESI-MS spectra showed a protonated, sodiated and deprotonated molecule at $\mathrm{m} / \mathrm{z} 611.1, \mathrm{~m} / \mathrm{z} 633.1$ and at $\mathrm{m} / \mathrm{z}$ 608.7, respectively. The MS/MS spectrum on precursor ion at $\mathrm{m} / z 608.7$ exhibited fragments at $\mathrm{m} / z 590.8$ (M-H-18), at $\mathrm{m} / \mathrm{z} 518.7(\mathrm{M}-\mathrm{H}-90)^{-}$and a base peak at $\mathrm{m} / \mathrm{z} 488.8$

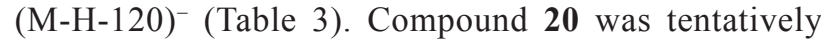
characterized as luteolin-6,8-di-C-glucoside. The ESIMS spectra for compound 21 at $17.4 \mathrm{~min}$ also showed protonated, sodiated and deprotonated molecule at $\mathrm{m} / \mathrm{z}$ $611.1, \mathrm{~m} / \mathrm{z} 633.1$ and at $\mathrm{m} / \mathrm{z} 609.0$ (Table 3), respectively. The MS/MS fragmentation pattern was typical of an di- $O, C$-glycosylflavone, exhibiting a base peak at $\mathrm{m} / \mathrm{z}$ 446.8 (M-H-162)-, what suggested an $O$-glycosilation with a hexose at the 7-O position of aglycone and a fragment at $\mathrm{m} / \mathrm{z} 326.8(286+41)$ suggesting luteolin as aglycone. Compound $\mathbf{2 1}$ was tentatively characterized as orientin-7-O-rhamnoside.

The ESI-MS spectra for compound $\mathbf{2 2}$ at 19.8 min exhibited a protonated, sodiated and deprotonated molecule at $\mathrm{m} / \mathrm{z} 595.1, \mathrm{~m} / \mathrm{z} 617.1$ and at $\mathrm{m} / \mathrm{z} 592.8$, respectively. The MS/MS fragmentation pattern was also typical of an di-O,C-glycosylflavone, exhibiting fragments at $\mathrm{m} / \mathrm{z} 472.7(\mathrm{M}-\mathrm{H}-120)^{-}$, a base peak at $\mathrm{m} / \mathrm{z} 430.8$ (M-H-162)- (Table 3), indicating an $O$-glycosilation with a hexose at the 7-O-position of aglycone and a fragment ion at $\mathrm{m} / \mathrm{z} 310.7(270+41)$ suggesting apigenin as aglycone. Compound 22 was characterized as vitexin-7-O-glucoside.

For compound $\mathbf{2 3}$ at $20.3 \mathrm{~min}$, the ESI-MS spectrum gave deprotonated molecule at $\mathrm{m} / \mathrm{z}$ 447.1, which fragmented further giving fragment ions at $\mathrm{m} / \mathrm{z}$ $357.0(\mathrm{M}-\mathrm{H}-90)^{-}$and a base peak at $m / z 327.0(\mathrm{M}-\mathrm{H}-$ $120)^{-}$, suggesting that the mono- $C$-glycosylation is in position 8 (Table 3 ). Thus, the absence of the loss 
of $18 \mathrm{u}$, indicate that the sugar substituent is located in position 8 (Ferreres et al., 2007; Abad-Garcia et al., 2008, 2009). Compound $\mathbf{2 3}$ was tentatively characterized as 8 - $C$-glucosyl luteolin, also known as orientin. Cyanogenic glycoside $\mathbf{1 2}$ was also found in $P$. bahiensis.

\section{Passiflora coccinea}

In the hydroalcoholic extract of $P$. coccinea were found procyanidin derivatives (dimeric species), flavones- $C$-glycosides, flavones-8,7-di- $O, C$ glycosides and one flavone- $O$-diglucoside. Condensed tannins consist of polyhydroxyflavan subunits with interflavonoid $C$ - $C$-linkages. Procyanidins consist exclusively of catechin and epicatechin units, ranging from dimers to polymers. Proanthocyanidins that contain (epi)afzelechin or (epi)gallocatechin as subunits are called propelargonidins or prodelphinidins. UV spectra of procyanidins showed maximum absorption at 280 $\mathrm{nm}$. In the MS/MS spectra, the major fragmentation routes of procyanidins are quinone methide fission, retro Diels-Alder fission and heterocyclic ring fission.
Fragments indicatives of water loss are also observed. For A- and B-type dimers, the difference in retention time is due to linkage or stereochemistry. A-type dimers are less polar than B-type due to their additional bond (Furuuchi et al., 2011).

For compound 26 at $11.9 \mathrm{~min}$, the ESI-MS spectra exhibited a deprotonated, protonated and sodiated molecule at $\mathrm{m} / \mathrm{z} 577.1, \mathrm{~m} / \mathrm{z} 579.1, \mathrm{~m} / \mathrm{z} 599.2$, respectively. The MS/MS spectrum on precursor ion at $m / z 577.1$ gave several product ions characteristic of procyanidins (M-H-18) $)^{-}$at $m / z$ 559.0, (M-H-126) at $\mathrm{m} / \mathrm{z}$ 451.0, due to heterocyclic ring fission (HRF); a base peak (M-H-152) $)^{-}$at $\mathrm{m} / \mathrm{z}$ 425.0, due to retro Diels-Alder fission (RDA); (M-H-170) ${ }^{-}$at $\mathrm{m} / z$ 407.1, and (M-H-288) at $m / z 289.3$ (catechin) (Table 4). The MS/MS spectrum on precursor ion at $\mathrm{m} / z 579.1$ gave fragments at $m / z 561.9(\mathrm{M}+\mathrm{H}-18)^{+}$, at $m / z 427.0$, due to retro Diels-Alder fission and at $\mathrm{m} / z$ 409.0. Compound 26 was tentatively characterized as procyanidin dimer B.

Other procyanidin derivatives were found at 10.7 min (compound 25), 16.1 min (compound 27) and 17.4 min (compound 28). The ESI-MS spectrum

Table 3. flavones- $C$-glycosides found in hydroethanolic extract of Passiflora bahiensis.

\begin{tabular}{|c|c|c|c|c|c|c|}
\hline Compound & $\begin{array}{c}\mathrm{RT} \\
(\mathrm{min})\end{array}$ & $\begin{array}{l}\mathrm{UV} \lambda_{\max } \\
(\mathrm{nm})\end{array}$ & $\begin{array}{c}(\mathrm{ESI})^{+} \\
(\mathrm{m} / z \text { abundance })\end{array}$ & $\begin{array}{c}(\mathrm{ESI})^{-} \\
(\mathrm{m} / z \text { abundance })\end{array}$ & Proposed structure & References \\
\hline 20 & 16.2 & $\begin{array}{c}260 \\
270,350\end{array}$ & $\begin{array}{l}\text { MS: }(\mathrm{M}+\mathrm{H})^{+} 611.1 \\
(\mathrm{M}+\mathrm{Na})^{+} 633.1\end{array}$ & $\begin{array}{l}\text { MS: } 608.7 ; \text { MS/MS: } \\
590.8(10), 518.7(20) \\
488.8(100)\end{array}$ & luteolin-6,8-di- $C$-glucoside & Figueirinha et al., 2008 \\
\hline 21 & 17.4 & 270,350 & $\begin{array}{l}\text { MS: }(\mathrm{M}+\mathrm{H})^{+} 611.1 \\
(\mathrm{M}+\mathrm{Na})^{+} 633.1\end{array}$ & $\begin{array}{l}\text { MS: } 609.0 ; \text { MS/MS: } \\
446.8(100), 326.7(20)\end{array}$ & orientin-7-O-glucoside & Ferreres et al., 2007 \\
\hline 2 & 17.6 & 270,340 & $\begin{array}{l}\text { MS: }(\mathrm{M}+\mathrm{H})^{+} 595.1 ; \\
\mathrm{MS} / \mathrm{MS}: 577.1(100), \\
559.0(40), 529.0(60), \\
511.0(50), 457.1(50) \\
(\mathrm{M}+\mathrm{Na})^{+} 617.1\end{array}$ & $\begin{array}{l}\text { MS: } 593.0 ; \text { MS/MS: } \\
574.9(20), 502.8(20), \\
472.8(100), 382.8(20), \\
352.7(20) .\end{array}$ & vicenin-2 & $\begin{array}{l}\text { Piccinelli et al., } 2008 \text {; } \\
\text { Negri et al., } 2012\end{array}$ \\
\hline 22 & 19.8 & $\begin{array}{c}260 \\
270,350\end{array}$ & $\begin{array}{l}\text { MS: }(\mathrm{M}+\mathrm{H})^{+} 595.1 \\
(\mathrm{M}+\mathrm{Na})^{+} 617.1\end{array}$ & $\begin{array}{l}\text { MS: } 592.8 ; \text { MS/MS: } \\
472.7(50), 430.8(100), \\
310.7(70)\end{array}$ & vitexin-7-O-glucoside & Ferreres et al., 2007 \\
\hline 23 & 20.3 & 270,338 & MS: $(\mathrm{M}+\mathrm{H})+449.0$ & $\begin{array}{l}\text { MS: 447.0; MS/MS: } \\
356.7(50), 326.7(100)\end{array}$ & orientin & $\begin{array}{l}\text { Piccinelli et al., } 2008 \text {; } \\
\text { Negri et al., } 2012\end{array}$ \\
\hline 24 & 23.5 & 300,330 & $\begin{array}{l}\text { MS: }(\mathrm{M}+\mathrm{H})^{+} 693.2 \\
(\mathrm{M}+\mathrm{Na})^{+} 715.2\end{array}$ & $\begin{array}{l}\text { MS: } 691.1 ; \text { MS/MS: } \\
658.9(70), 630.9(80) \text {, } \\
334.6(100)\end{array}$ & $\begin{array}{l}\text { feruloylquinic acid } \\
\text { diglucoside }\end{array}$ & \\
\hline 12 & 34.9 & & $\begin{array}{l}\text { MS: }(\mathrm{M}+\mathrm{H})^{+} 332.2 \\
\text { MS/MS: } 314.2(100) \\
270.2(50), 252.2(30)\end{array}$ & & dhurrinamide derivative & $\begin{array}{l}\text { Sendker \& Nahrstedt, } \\
2010\end{array}$ \\
\hline
\end{tabular}<smiles>[R]c1ccc(-c2cc(=O)c3c(O)cc(OC(O)C4OC(CO)C(O)C(O)C4O)c([R])c3o2)cc1O</smiles>

$21 \mathrm{R}_{1}=\mathrm{OH} ; \mathrm{R}_{2}=\mathrm{Glc}$ $22 \mathrm{R}_{1}=\mathrm{H} ; \mathrm{R}_{2}=\mathrm{Glc}$<smiles>[R20]c1ccc(/C=C/C(=O)O[C@@H]2C[C@](O)(C(=O)O)C[C@@H](O)[C@H]2O)cc1OC</smiles>

24

$\mathrm{R}=$ diglucoside 
of compound $\mathbf{2 5}$ exhibited a deprotonated molecule at $m / z$ 865.2, which fragmented further to give fragments at $m / z 846.9(\mathrm{M}-\mathrm{H}-18)^{-}, \mathrm{m} / \mathrm{z} 738.9(\mathrm{M}-\mathrm{H}-126)^{-}$, a base peak at $\mathrm{m} / \mathrm{z} 694.8(\mathrm{M}-\mathrm{H}-170)^{-}$and a fragment at $\mathrm{m} / \mathrm{z}$ 576.8 (M-H-288)- (Table 4). The MS/MS fragment ion at $\mathrm{m} / z 738.9$ is corresponding to the loss of $126 \mathrm{u}$ indicating HRF dissociation pathway for this molecule. This compound followed the dissociation pathways of B-type dimer. Comparison of these data with those described in the literature (Furuuchi et al., 2011) allowed the identification of procyanidin trimer. Compound $\mathbf{2 5}$ was tentatively characterized as procyanidin trimer.

The ESI-MS spectrum of compound 27 showed a deprotonated molecule at $\mathrm{m} / \mathrm{z}$ 849.1 (Table 4). The MS/MS spectrum of deprotonated molecule at $m / z 849.1$ gave fragments at $m / z 830.9(\mathrm{M}-\mathrm{H}-18)^{-}$, at $\mathrm{m} / z 722.9$ (M-H-126) $)^{-}$, at $m / z 696.8$ (M-H-152)- a base peak at $\mathrm{m} / \mathrm{z} 576.8$ and a fragment at $\mathrm{m} / \mathrm{z} 558.6$. The MS/ MS fragment ion at $m / z 722.9$ corresponding to the loss of $126 \mathrm{u}$ indicated HRF dissociation pathway for this molecule and the formation of the $\mathrm{m} / \mathrm{z} 696.8$ via loss of $152 \mathrm{u}$, showed that RDA occurred to a lesser extent (Furuuchi et al., 2011). For compound 28, the ESI-MS spectrum gave a deprotonated molecule at $\mathrm{m} / \mathrm{z}$ 833.2. The MS/MS spectrum of deprotonated molecule at $\mathrm{m} / \mathrm{z}$ 833.2 gave fragments ions at $m / z 814.9(\mathrm{M}-\mathrm{H}-18)^{-}$, at $m / z 706.9$ (M-H-126) $)^{-}$, at $m / z 560.8(\mathrm{M}-\mathrm{H}-272)^{-}$, and a base peak at $\mathrm{m} / \mathrm{z} 542.9$. The MS/MS fragment ion at $\mathrm{m} / \mathrm{z}$ 706.9 corresponding to the loss of $126 \mathrm{u}$ indicated HRF dissociation pathway for this molecule. Comparison of these data with those described in the literature (Sarnoski et al., 2012) allowed the identification of compound $\mathbf{2 7}$ and $\mathbf{2 8}$ as propelargonidin trimer.

Peaks at 19.8, 20.3, 21.5 and 22.8 min (Table 4) showed a UV spectrum characteristic of flavones. Compounds 22 (at $19.8 \mathrm{~min}$ ) and 23 (at $20.3 \mathrm{~min}$ ) were also found in P. bahiensis, while that compound $\mathbf{8}$ (at $22.8 \mathrm{~min}$ ) was also found in P. sidifolia. The ESI-MS spectra of compound 29 at $21.5 \mathrm{~min}$ showed protonated and deprotonated molecule at $\mathrm{m} / \mathrm{z} 595.3$ and at $\mathrm{m} / \mathrm{z}$ 593.1, respectively (Table 4). The sequential MS/MS fragmentation of $\mathrm{m} / \mathrm{z} 593.1$ allowed the observation of a base peak at $\mathrm{m} / \mathrm{z} 269.0$, due to the loss of $324 \mathrm{u}$ (two hexoses, probably glucoses). This fragmentation behavior is consistent with flavones- $O$-diglycoside. Compound 29 was tentatively characterized as apigenin7-O-diglucoside.

\section{Passiflora vitifolia}

In the hydroethanolic extract of $P$. vitifolia were detected flavones- $O$-triglycosides, flavones-8,7di- $C, O$-glycosides and flavones- $C$-glycosides. Peaks at $10.7,12.8,17.4,19.8,20.5,21.5$ and $22.8 \mathrm{~min}$ (Table 5) showed UV spectra characteristic of flavones. The ESI-MS spectra of compound $\mathbf{3 0}$ at $10.7 \mathrm{~min}$ exhibited protonated, sodiated and deprotonated molecules at $741.1,763.2$ and at $\mathrm{m} / \mathrm{z} 739.1$, respectively. For

Table 4. Constituents found in hydroethanolic extract of Passiflora coccinea.

\begin{tabular}{|c|c|c|c|c|c|c|}
\hline Compound & $\begin{array}{c}\mathrm{RT} \\
(\mathrm{min})\end{array}$ & $\begin{array}{l}\mathrm{UV} \lambda_{\max } \\
(\mathrm{nm})\end{array}$ & $\begin{array}{c}(\mathrm{ESI})^{+} \\
(\mathrm{m} / z \text { abundance })\end{array}$ & $\begin{array}{c}(\text { ESI) } \\
(m / z \text { abundance })\end{array}$ & Proposed structure & References \\
\hline 25 & 10.7 & 280 & & $\begin{array}{l}\text { MS: } 865.2 ; \text { MS/MS: } \\
846.9,(30), 738.9(70) \\
694.8(100), 576.8(20)\end{array}$ & $\begin{array}{l}\text { procyanidin trimer } \mathrm{C} 1 \\
\text { (catechin-catechin-catechin) }\end{array}$ & $\begin{array}{l}\text { Furuuchi et al., 2011; } \\
\text { Sarnoski et al., } 2012\end{array}$ \\
\hline 26 & 11.9 & 280 & $\begin{array}{l}\text { MS: }(\mathrm{M}+\mathrm{H})^{+} 579.1 \\
\text { MS/MS: } 561.9(40) \\
427.0(100), 409.0(80)\end{array}$ & $\begin{array}{l}\text { MS: } 577.1 ; \text { MS/MS: } \\
559.0(70), 451.0(30), \\
425.0(100), 407.1(60), \\
289.3(20)\end{array}$ & procyanidin dimer B1 & $\begin{array}{l}\text { Furuuchi et al., 2011; } \\
\text { Sarnoski et al., } 2012\end{array}$ \\
\hline 27 & 16.1 & 280 & & $\begin{array}{l}\text { MS: } 849.1 ; \text { MS/MS: } \\
830.9(30), 722.9(80), \\
696.8(20), 576.8(100), \\
558.6(80)\end{array}$ & propelargonidin trimer & $\begin{array}{l}\text { Furuuchi et al., 2011; } \\
\text { Sarnoski et al., } 2012\end{array}$ \\
\hline 28 & 17.4 & 280 & & $\begin{array}{l}\text { MS: } 833.2 ; \text { MS/MS: } \\
814.9(30), 706.9(80), \\
560.8(70), 542.9(100)\end{array}$ & propelargonidin trimer & $\begin{array}{l}\text { Furuuchi et al., 2011; } \\
\text { Sarnoski et al., } 2012\end{array}$ \\
\hline 22 & 19.8 & $\begin{array}{c}260 \\
270,350\end{array}$ & $\begin{array}{l}\text { MS: }(\mathrm{M}+\mathrm{H})^{+} 595.1 \\
(\mathrm{M}+\mathrm{Na})^{+} 617.1\end{array}$ & $\begin{array}{l}\text { MS: } 592.8 ; \text { MS/MS: } \\
472.7(50), 430.8(70) \text {, } \\
310.7(100)\end{array}$ & vitexin-7-O-glucoside & Ferreres et al., 2007 \\
\hline 23 & 20.3 & 270,338 & MS: $(\mathrm{M}+\mathrm{H})^{+} 449.0$ & $\begin{array}{l}\text { MS: 447.0; MS/MS: } \\
356.7(50), 326.7 \text { (100) }\end{array}$ & orientin & $\begin{array}{l}\text { Piccinelli et al., 2008; } \\
\text { Negri et al., } 2012\end{array}$ \\
\hline 29 & 21.5 & & MS: $(\mathrm{M}+\mathrm{H})^{+} 595.3$ & $\begin{array}{l}\text { MS: 593.1; MS/MS: } \\
269.0(100)\end{array}$ & apigenin-7-O-diglucoside & $\begin{array}{l}\text { Abad-Garcia et al., 2008, } \\
2009\end{array}$ \\
\hline 8 & 22.8 & 270,340 & & $\begin{array}{l}\text { MS: 431.2; MS/MS: } \\
340.7(35), 310.7(100)\end{array}$ & vitexin & Grundman et al., 2008 \\
\hline
\end{tabular}


<smiles>[R]OC1Cc2c(O)cc(O)c([C@H]3c4c(O)cc(O)cc4O[C@H](c4ccc(O)c(O)c4)[C@H]3O)c2O[C@H]1c1ccc(O)c(O)c1</smiles>

$25 \mathrm{R}=$ catechin 27 and $28 \mathrm{R}=$ afzelechin<smiles>Oc1cc(O)c2c(c1)O[C@H](c1ccc(O)c(O)c1)[C@H](O)[C@H]2c1c(O)cc(O)c2c1O[C@H](c1ccc(O)c(O)c1)[C@H](O)C2</smiles>

26<smiles>[R20]Oc1cc(O)c2c(=O)cc(-c3ccc([R])c(O[R2])c3)oc2c1</smiles>

$29 \mathrm{R}_{1}=\mathrm{R}_{2}=\mathrm{H} ; \mathrm{R}_{3}=$ diglucoside

$30 \mathrm{R}_{1}=\mathrm{OH} ; \mathrm{R}_{2}=\mathrm{Glc} ; \mathrm{R}_{3}=$ dirhamnoside

$31 \mathrm{R}_{1}=\mathrm{OH} ; \mathrm{R}_{2}=$ dirhamnoside; $\mathrm{R}_{3}=$ rhamnose

flavonoids- $O$-glycosides, the sugar moieties are easily lost by neutral losses (Abad-Garcia et al., 2008, 2009). The MS/MS spectrum of protonated molecule at $\mathrm{m} / \mathrm{z}$ 741.1 , showed a fragment at $m / z 579.1$, corresponding to the loss of hexose, Generally, the 3-O and 7-Oglycosides in flavonoids 3,7-di- $O$-glycosides can readily be located on the basis of ESI-MS/MS. While the loss of 3-O-glycoside is more abundant than that the 7-O-glycoside for protonated molecules; the opposite behavior is observed for deprotonated and sodiated molecules (Kachlicki et al., 2008). The fragment at $\mathrm{m} / \mathrm{z}$ 579.1 , corresponds to the loss of hexose of protonated molecule. This fact suggested that this substituent, probably is linked to 3 '-O-position of luteolin. Compound $\mathbf{3 0}$ was tentative characterized as luteolin7-O-dirhamnoside-3'-O-glucoside.

The ESI-MS spectra of compound $\mathbf{3 1}$ at 12.8 min showed a protonated and a deprotonated molecule at $\mathrm{m} / \mathrm{z} 725.1$ and at $\mathrm{m} / \mathrm{z} 723.1$, respectively (Table 5). The MS/MS spectrum of deprotonated molecule at $\mathrm{m} / \mathrm{z}$ 723.1 showed a fragment at $\mathrm{m} / \mathrm{z} 577.1$, corresponding to the loss of rhamnose. For deprotonated molecule the loss of $7-O$-glycoside is more abundant, thus in this case the substituent rhamnose, probably is linked in 7-O-position of luteolin. Compound $\mathbf{3 1}$ was tentative characterized as luteolin-3'- $O$-dirhamnoside7-O-rhamnoside. Compound 5 (at $20.5 \mathrm{~min}$ ) and $\mathbf{8}$ (at $22.8 \mathrm{~min}$ ) were also found in P. sidifolia, while that compounds 21 (at $17.4 \mathrm{~min}$ ) and $\mathbf{2 2}$ (at $19.8 \mathrm{~min}$ ) were also found in $P$. bahiensis and $P$. coccinea, respectively and compound 29 (at $21.5 \mathrm{~min}$ ) was also found in $P$. coccinea.

The presence of flavones glycosides could be detected in all extracts from the aerial parts of these five South American Passiflora species, although all of them exhibited different HPLC profiles. As can be seen in Tables 1 to 5 , flavones which were found in more than one species were orientin-7-O-glucosidecompound 21 (P. bahiensis and P. vitifolia), vicenin-2compound 2 ( $P$. sidifolia and P. bahiensis), vitexin-7-Oglucoside-compound 22 ( $P$. bahiensis, $P$. coccinea and $P$. vitifolia), orientin-compound 23 ( $P$. bahiensis and $P$. coccinea), apigenin-7- $O$-dihexoside-compound $\mathbf{2 9}$ ( $P$. coccinea and $P$. vitifolia), vitexin-2"-O-glucosidecompound 6 ( $P$. sidifolia and $P$. quadrangularis), vitexin-2"- $O$-xyloside-compound 7 ( $P$. sidifolia and $P$. quadrangularis) and vitexin-compound 8 ( $P$. sidifolia, $P$. coccinea and $P$. vitifolia). Cyclopassiflosides were found only in $P$. quadrangularis, cyanogenic glycosides in $P$. quadrangularis and $P$. bahiensis, and procyanidins also only in $P$. coccinea. Flavonoids are compounds biologically actives, however according to Butterweck \& Nahrstedt (2012), the route of administration can determine the biological activity of flavonoids, which can acted also as potential prodrugs, that are metabolized by intestinal microflora to their corresponding hydroxyphenylacetic acids. In studies carried by these same authors, hydroxyphenylacetic acids obtained through the metabolized flavonoids showed anxyolitic activity.

\section{Conclusion}

The occurrence of flavones- $C$-glycosides, cyclopassiflosides and cyanogenic glycosides in Passiflora species is known. The results obtained here showed that these species possess different chemical composition, justifying the importance of studies 
Table 5. Flavonoids found in in hydroethanolic extract of Passiflora vitifolia.

\begin{tabular}{|c|c|c|c|c|c|c|}
\hline Compound & $\begin{array}{c}\mathrm{RT} \\
(\mathrm{min})\end{array}$ & $\begin{array}{c}\mathrm{UV} \lambda_{\max } \\
(\mathrm{nm})\end{array}$ & $\begin{array}{c}\left(\mathrm{ESI}^{+}\right. \\
(\mathrm{m} / \mathrm{z} \text { abundance })\end{array}$ & $\begin{array}{c}(\text { ESI) } \\
(m / z \text { abundance })\end{array}$ & Proposed structure & References \\
\hline 30 & 10.7 & 270,350 & $\begin{array}{l}\text { MS: }(\mathrm{M}+\mathrm{H})^{+} 741.1 ; \\
\text { MS/MS: } 579.1 ; \\
(\mathrm{M}+\mathrm{Na})^{+} 763.3\end{array}$ & MS: 739.1 & $\begin{array}{l}\text { luteolin-7- } O \text {-dirhamnoside } \\
\text { 3'-O-glucoside }\end{array}$ & Kachlicki et al., 2008 \\
\hline 31 & 12.8 & 270,350 & MS: $(\mathrm{M}+\mathrm{H})^{+} 725.1$ & $\begin{array}{l}\text { MS: 723.1; MS/MS: } \\
577.1(100)\end{array}$ & $\begin{array}{l}\text { luteolin-3'-O-dirhamnoside- } \\
\text { 7-O-rhamnoside }\end{array}$ & Kachlicki et al., 2008 \\
\hline 21 & 17.4 & 270,350 & $\begin{array}{l}\text { MS: }(\mathrm{M}+\mathrm{H})^{+} 611.1 \\
(\mathrm{M}+\mathrm{Na})^{+} 633.1\end{array}$ & $\begin{array}{l}\text { MS: } 609.0 ; \text { MS/MS: } \\
446.8(100), 326.7(20)\end{array}$ & orientin-7-O-glucoside & Ferreres et al., 2007 \\
\hline 22 & 19.8 & 270,340 & $\begin{array}{l}\text { MS: }(\mathrm{M}+\mathrm{H})^{+} 595.1 \\
(\mathrm{M}+\mathrm{Na})^{+} 617.1\end{array}$ & $\begin{array}{l}\text { MS: } 592.8 ; \text { MS/MS: } \\
472.7(50), 430.8(100) \text {, } \\
310.7(70)\end{array}$ & vitexin-7-O-glucoside & Ferreres et al., 2007 \\
\hline 5 & 20.5 & 270,350 & & $\begin{array}{l}\text { MS: 447.1; MS/MS: } \\
428.8(20), 356.9(70) \text {, } \\
326.9(100)\end{array}$ & isoorientin & $\begin{array}{l}\text { Abad-Garcia et al., } 2008 \text {; } \\
\text { Figueirinha et al., } 2008\end{array}$ \\
\hline 29 & 21.5 & & MS: $(\mathrm{M}+\mathrm{H})^{+} 595.3$ & $\begin{array}{l}\text { MS: 593.1; MS/MS: } \\
269.0(100)\end{array}$ & apigenin-7-O-diglucoside & $\begin{array}{l}\text { Abad-Garcia et al., 2008, } \\
2009\end{array}$ \\
\hline 8 & 22.8 & 270,340 & & $\begin{array}{l}\text { MS: 431.2; MS/MS: } \\
340.7(35), 310.7(100)\end{array}$ & vitexin & Grundman et al., 2008 \\
\hline
\end{tabular}

aiming for the chemical characterization of different Passiflora species. The anxiolytic activity of the Passiflora species has been attributed to flavonoids by several authors, and among the species presented in this paper, flavonoids are found as main constituents in P. sidifolia, P. bahiensis, P. coccinea and P. vitifolia, but only in $P$. sidifolia a flavone-6,8-di-C-glycoside, apigenin-6- $C$-rhamnosyl-8- $C$-arabinoside, was found as the main constituent. Cyclopassiflosides are found in high content together cyanogenic glycosides in $P$. quadrangularis, while procyanidins were found in $P$. coccinea.

\section{Acknowledgement}

The authors thank Dr. E. A. Carlini for the intellectual support, the Plantarum Institute and coworkers for kindly providing all the vegetal material used in this study, and FAPESP and AFIP for the financial support.

\section{References}

Abad-Garcia B, Garmon-Lobato S, Berrueta LA, Gallo B, Vicente F 2008. New features on the fragmentation and differentiation of $C$-glycosidic flavone isomers by positive electrospray ionization and triple quadrupole mass spectrometry. Rapid Commun Mass Sp 22: 18341842.

Abad-Garcia B, Berrueta LA, Garmon-Lobato S, Gallo B, Vicente F 2009. A general analytical strategy for the characterization of phenolic compounds in fruit juices by high-performance liquid chromatography with diode array detection coupled to electrospray ionization and triple quadrupole mass spectrometry. $J$ Chromatogr A 1216: 5398-5415.

Abourashed EA, Vanderplanck JR, Khan IA 2002. Highspeed extraction and HPLC fringerprint of medicinal plants- I. Application to Passiflora flavonoids. Pharm Biol 40: 81-91.

Antognoni F, Zheng SP, Pagnucco C, Baraldi R, Poli F, Biondi $\mathrm{S} 2$ 2007. Induction of flavonoid production by UV-B radiation in Passiflora quadrangularis callus cultures. Fitoterapia 78: 345-352.

Appel K, Rose T, Fiebich B, Kammler T, Hoffmann C, Weiss G 2011. Modulation of the gamma-aminobutyric acid (GABA) system by Passiflora incarnata L. Phytother Res 25: 838-843.

Aslanargun P, Cuvas O, Dikmen B, Aslan E, Yuksel MU 2012. Passiflora incarnata Linneaus as an anxiolytic before spinal anesthesia. J Anesth 26: 39-44.

Barbosa PR, Valvassori SS, Bordignon CL, Kappel VD, Martins MR, Gavioli EC, Quevedo J, Reginato FH 2008. The aqueous extracts of Passiflora alata and Passiflora edulis reduce anxiety-related behaviors without affecting memory process in rats. J Med Food 11: 282-288.

Butterweck V, Nahrstedt A 2012. What is the best strategy for preclinical testing of botanicals? A critical perspective. Planta Med 78: 747-754.

Bylov T, Franzyk H, Jaroszewski JW 2004. Cyclopentanoid cyanohydrin glucosides from Passiflora mixta. Biochem Syst Ecol 32: 695-698.

Carvalho FKD, de Medeiros RMT, de Araujo JAS, RietCorrea F 2011. Experimental poisoning by Passiflora foetida (Passifloraceae) in goats. Pesquisa Vet Brasil 31: 477-481.

de Castro PCF, Hoshino A, da Silva JC, Mendes FR 2007. 
Possible anxiolytic effect of two extracts of Passiflora quadrangularis L. in experimental models. Phytother Res 21: 481-484.

Dhawan K, Dhawan S, Sharma A 2004. Passiflora: a review update. J Ethnopharmacol 94: 1-23.

Fernandez SP, Nguyen M, Yow TT, Chu C, Johnston GAR, Hanrahan JR, Chebib M 2009. The flavonoid glycosides, myricitrin, gossypin and naringin exert anxiolytic action in mice. Neurochem Res 34: 18671875.

Ferreres F, Gil-Izquierdo A, Andrade PB, Valentao P, TomasBarberan FA 2007. Characterization of $C$-glycosyl flavones $O$-glycosylated by liquid chromatographytandem mass spectrometry. J Chromatogr A 1161: 214-223.

Fiebich BL, Knörle R, Appel K, Kammler T, Weiss G 2011. Pharmacological studies in an herbal drug combination of St. John's Wort (Hypericum perforatum) and passion flower (Passiflora incarnata): In vitro and in vivo evidence of synergy between Hypericum and Passiflora in antidepressant pharmacological models. Fitoterapia 82: 474-480.

Figueirinha A, Paranhos A, Perez-Alonso JJ 2008. Cymbopogon citratus leaves: Characterisation of flavonoids by HPLC-PDA-ESI/MS/MS and an approach to their potential as a source of bioactive polyphenols. Food Chem 110: 718-728.

Furuuchi Ryo, Yokoyama T, Watanabe Y, Hirayama M 2011. Identification and quantification of short oligomeric proanthocyanidins and other polyphenols in boysenberry seeds and juice. J Agric Food Chem 59: 3738-3746.

Gouveia S, Castilho PC 2011. Characterisation of phenolic acid derivatives and flavonoids from different morphological parts of Helichrysum obconicum by a RP-HPLC-DAD-(-)-ESI-MS(n) method. Food Chem 129: 333-344.

Grice ID, Ferreira LA, Griffiths LR 2001. Identification and simultaneous analysis of hamane, harmina, harmol, isovitexin, and vitexin in Passiflora incarnata extracts with a novel HPLC method. J Liq Chromatogr R T 24: 2513-2523.

Grundmann O, Wang J, McGregor GP, Butterweck V 2008. Anxiolytic activity of a phytochemically characterized Passiflora incarnata extract is mediated via the GABAergic system. Planta Med 74: 1769-1773.

Jaroszewski JW, Olafsdottir ES, Wellendorph P, Christensen J, Franzyk H, Somanadhan B, Budnik BA, Jorgensen LB, Clausen V 2002. Cyanohydrin glycosides of Passiflora: distribution pattern, a saturated cyclopentane derivative from $P$. guatemalensis, and formation of pseudocyanogenic alpha-hydroxyamides as isolation artefacts. Phytochemistry 59: 501-511.

Junqueira KP, Faleiro FG, Junqueira NTV, Bellon G, Ramos JD, Braga MF, de Souza LS 2008. Confirmation of interspecific hybrids in Passiflora using molecular markers. Re Bras Frutic 30: 191-196.

Kachlicki P, Einhorn J, Muth D, Kerhoas L, Stobiecki M 2008. Evaluation of glycosylation and malonylation patterns in flavonoid glycosides during LC/MS/MS metabolite profiling. J Mass Spectrom 43: 572-586.

Lakhan SE, Vieira KF 2010. Nutritional and herbal supplements for anxiety and anxiety-related disorders: systematic review. Nutr J 42: 1-14.

Li HW, Zhou P, Yang QQ, Shen Y, Deng J, Li L, Zhao D 2011. Comparative studies on anxiolytic activities and flavonoid compositions of Passiflora edulis 'edulis' and Passiflora edulis 'flavicarpa'. J Ethnopharmacol 133: 1085-1090.

Liu GZ, Ma JY, Chen YZ, Tian QQ, Shen Y, Wang XS, Chen B, Yao SZ 2009. Investigation of flavonoid profile of Scutellaria bacalensis Georgi by high performance liquid chromatography with diode array detection and electrospray ion trap mass spectrometry. J Chromatogr A 1216: 4809-4814.

Liu GZ, Rajesh M, Wang XS, Zhang M, Wu Q, Li S, Chen B, Yao SZ 2011. Identification of flavonoids in the stems and leaves of Scutellaria bacalensis Georgi. $J$ Chromatogr B 879: 1023-1028.

Lutomski J, Malek B 1975. Pharmakochemische untersuchungen der drogen der gattung Passiflora. IV. Mittlg: der vergleich des alkaloidgehaltes in verschiedenen harmandrogen. Planta Med 27: 381384.

Lutomski J, Malek B, Rybacka L 1975. Pharmacochemical investigation of the raw materials from Passiflora genus. II. The pharmacochemical estimation of juices from the fruits of Passiflora edulis and Passiflora edulis forma flavicarpa. Planta Med 27: 112-121.

Mendes FR, Mattei R, Carlini EA 2002. Activity of Hypericum brasiliense and Hypericum cordatum on the central nervous system in rodents. Fitoterapia 73: 462-471.

Negri G, Teixeira EW, Alves MLTMF, Moreti ACCC, Otsuk IP, Borguini GB, Salatino A 2011. Hydrocinnamic acid amide derivatives, phenolic compounds and antioxidant activity of extracts of pollen samples from Southeast Brazil. J Agric Food Chem 59: 5516-5522.

Negri G, Santi D, Tabach R 2012. Chemical composition of hydroethanolic extracts from Siparuna guianensis, medicinal plant used as anxiolytics in Amazon region. Rev Bras Farmacogn 22: doi: 10.1590/S0102695X2012005000034.

Orsini F, Pelizzoni F, Ricca G, Verotta L 1987. Triterpene glycosides related to quadranguloside from Passiflora quadrangularis. Phytochemistry 26: 1101-1105.

Orsini F, Pelizzoni F, Verotta L 1986. Quadranguloside, a cycloartane triterpene glycoside from Passiflora quadrangularis. Phytochemistry 25: 191-193.

Osorio C, Duque C, Fujimoto Y 2000. Oxygenated monoterpenoids from badea (Passiflora quadrangularis) 
fruit pulp. Phytochemistry 53: 97-101.

Piccinelli AL, Mesa MG, Armenteros DM, Alfonso MA, Arevalo AC, Campone L, Rastrelli L 2008. HPLCPDA-MS and NMR characterization of $C$-glycosyl flavones in a hydroalcoholic extract of Citrus aurantifolia leaves with antiplatelet activity. J Agric Food Chem 56: 1574-1581.

Rehwald A, Sticher O, Meier B 1995. Trace analysis of harman alkaloids in Passiflora incarnata by reversed phase high-performance liquid chromatography. Phytochem Analysis 6: 96-100.

Reginatto FH, Kauffmann C, Schripsema J, Guillaume D, Gosmann G, Schenkel EP. 2001. Steroidal and triterpenoidal glucosides from Passiflora alata. $J$ Braz Chem Soc 12: 32-36.

Reginatto FH, Gosmann G, Schripsema J, Schenkel EP 2004. Assay of quadranguloside, the major saponin of leaves of Passiflora alata, by HPLC-UV. Phytochem Analysis 15: 195-197.

Saeki D, Yamada T, Kajimoto T, Muraoka O, Tanaka R 2011. A set of two diastereomers of cyanogenic glycosides from Passiflora quadrangularis. Nat Prod Commun 6: 1091-1094.

Sarris J, Panossian A, Schweitzer I, Stough C, Scholey A 2012. Herbal medicine for depression, anxiety and insomnia: a review of psychopharmacology and clinical evidence. Eur Neuropsychopharm 21: 841860.

Sarnoski PJ, Johnson JV, Reed KA, Tanko JM, O'Keefe SF 2012. Separation and characterisation of proanthocyanidins in Virginia type peanut skins by LC-MS(n). Food Chem 131: 927-939.

Seigler DS, Pauli GF, Frohlich R, Wegelius E, Nahrstedt A, Glander KE, Ebinger JE 2005. Cyanogenic glycosides and menisdaurin from Guazuma ulmifolia, Ostrya virginiana, Tiquilia plicata, and Tiquilia canescens. Phytochemistry 66: 1567-1580.

Sendker J, Nahrstedt A 2010. Synthesis and characterisation of alpha-glycosyloxyamides derived from cyanogenic glycosides. Phytochem Analysis 21: 575-581.

Singh B, Singh D, Goel RK 2012. Dual protective effect of Passiflora incarnata in epilepsy and associated postictal depression. J Ethnopharmacol 139: 273-279.

Wohlmuth H, Penman KG, Pearson T, Lehmann RP 2010. Pharmacognosy and chemotypes of passionflower (Passiflora incarnata L.). Biol Pharm Bull 33: 10151018.

Yoshikawa K, Katsuta S, Mizumori J, Arihara S 2000a. New cycloartane triterpenoids from Passiflora edulis. $J$ Nat Prod 63: 1377-1380.

Yoshikawa K, Katsuta S, Mizumori J, Arihara S 2000b. Four cycloartane triterpenoids and six related saponins from Passiflora edulis. J Nat Prod 63: 1229-1234.

Zeraik ML, Yariwake JH 2010. Quantification of isoorientin and total flavonoids in Passiflora edulis fruit pulp by HPLC-UV/DAD. Microchem J 96: 86-91.

Zucolotto SM, Fagundes C, Reginatto FH, Ramos FA, Castellanos L, Duque C, Schenkel EP 2012. Analysis of $C$-glycosyl flavonoids from South American Passiflora species by HPLC-DAD and HPLC-MS. Phytochem Analysis 23: 232-239.

\section{*Correspondence}

Marna Eliana Sakalem

Department of Psychiatry and Psychotherapy, Laboratory for Molecular Psychiatry, Universität Münster

Albert-Schweitzer-Campus 1, D-48149 Münster, Germany

Marna.Sakalem@ukmuenster.de

Tel.: +492518357122

Fax: +492518357128 